\title{
INTRAVENOUS REGIONAL ANAESTHESIA A REPORT ON A NEW LOCAI ANAESTHETIC AGENT
}

\author{
R L HOOPER, BSC (PHM), M D *
}

A LOCAL ANAESTHETIC COMPOUND with reduced tomicity would be a welcome addition to the anaesthetsst's armamentarium, partucularly with the revival of interest in intravenous regional anaesthesia The clinical success enjoyed by lignocaine has led to the investigation of compounds with a similar chemical structure $^{1}$ One such compound is a-n-propylarnino 2-methylpropionanilide or Cilanest ${ }^{\mathrm{r}}$

Pharmacological tests and clinical trials in man have revealed that Citanest ${ }^{\mathrm{r}}$ has the same local anaesthetic potency as lignocaine However, Citanest ${ }^{\mathrm{r}}$ has a low toxicity (approximately 60 per cent that of lignocaine) because of its gond localization at the site of injection, a favourable ratio in distribution between cells and extracellular fluid, and a rapid breakdown by liver enzymes Tissue toxicity or local irritation is minimal ${ }^{2-5}$

A marked difference in both subjective and objective symptoms was recorded by Englesson et al ${ }^{6}$ with the intiavenous injection in man of $200 \mathrm{mg}$ of lignocaine and Citanest ${ }^{\mathbb{R}}$ Lignocame had a considerably more pronounced effect than Citanest ${ }^{\mathrm{R}}$ The subjective symptoms were varied, but were of the same type in each subject The symptoms noted were sleepmess, a sensation of cold, a feeling of pressure on the chest, auditory disturbances, headache or pressure on the forehead, numbness of the lips and tongue, as well as difficulty in talking Isolated twitching and $E E G$ changes were not observed with Citanest ${ }^{R}$ as they were in some cases with lignocame There were no signuficant thanges in heart rate, blood pressure, or arterial oxygen or carbon dioxide tension with enther drug In a small series, six subjects were given $400 \mathrm{mg}$ of Citanest intravenously Five of the subjects reacted only insignificantly and showed less pronounced symptoms than atter recelving $200 \mathrm{mg}$ of lignocane The suxth subject showed symptoms similar to those seen after receiving $200 \mathrm{mg}$ of lignocarne

\section{METHOD}

The intravenous use of lignocaine for sungical analgesid in the extremities at the Lagos University Teaching Hospital has been reported by Dawkins et al ${ }^{7}$ In the clinical trial reported here, a similar method was used in that sphygmomanometer cuff was applied to the affected extremity of the recumbent patient Followng unflation of the cuff to just above the diastolic blood pressure, venpuncture distal to the cuff was carred out using a $20 \mathrm{cc}$ syringe containing the Citanestir solution with an SWG 22 needle attached 'The cuff was then deflated, and whle the syminge was held in place, the extremity was elevated for one-half

- Serzor Registrar in Anaesthesia, Lagos University Teaching Hospital, Lagos, Nigena 
minute to allow venous drainage. The cuff was then inflated above systolic pressure, the extremity was returned to the horizontal position, and the solution of Citanest ${ }^{\mathrm{R}}$ was administered in a single injection Following the surgical procedure the sphygmomanometer cuff was deflated

Citanest $^{\mathrm{R}}$ hydrochloride in aqueous solutions of 05 per cent, 10 per cent, and 20 per cent was used in the clinical trial The dosage varied from $75 \mathrm{mg}$ to $800 \mathrm{mg}$

The onset and the termmation of analgesia were determined by testing the response to pin-prick In most instances the return of sensation was patchy in nature the end-point was noted when sensation returned to any portion of the anaesthetized area It was not unconmon to have a sensation of pain return to the surgical site before the return of skin sensitivity to pin-prick In these instances the end-point was noted with the onset of pain Two penods of analgesia were recorded, the period during which the sphygmomanometer cuff was inflated, and that following deflation of the cuff

A total of 64 patients received intravenous Citanest ${ }^{\mathrm{R}}$, one patient required surgery to both hands, thus accounting for 65 surgical procedures The surgical site was the upper extremity in 58 cases and the lower extremity in 7 cases The majority of patients had infections requirmg incision and drainage, but severe lacerations, dislocations, and fractures were also treated The blood pressure cuff was usually placed below the elbow or knee if such placement did not interfere with the surgical procedure In the few prolonged procedures involving the hand, the cuff was placed above the elbow and then, following analgesia, a second cuff was placed over the andesthetized area and inflated The removal of the first cuff then eliminated the discomfort of having a tourniquet on a non-anaesthetized area

The analgesıc response was gradled as good, moderate, or poor There was some difficulty in assessing the analgesic response because of the language barner However, those patients who grimaced or appeared to have some discomfort with surgical stimulation but made no attempt to withdraw the extremity involved and tolerated the surgical procedure were classified as moderate This classification was considered an acceptable result, as it was felt that the patients were probably reacting to the sensation of touch and pressure The iesponse was graded as poor if the patient withdiew the extremity or continued to be restless and was distressed by the surgical procedure

During the immediate postoperative period the patients were observed to note any toxic effects of the local anaes hetic drug The pulse was palpated to note any change in character, rate, or rhythm As most patients were sitting up and ambulatory within a few minutes, the blood pressure was not usually recorded

\section{RFSUlts}

Analgesia was usually present by the time the injection of Citanest ${ }^{R}$ was completed In a few cases the onset of analgesia did not occur for up to four minutes following the injection The period of analgesia with the tourniquet inflated ranged from 2 minutes to 1 hour and 29 minutes The duration of analge- 
sia following the deflation of the tourniquet was variable and ranged from 1 minute to $\mathbb{1}$ hour and 30 minutes This period of post-tourniquet analgesia seemed to be prolonged with the stronger solutions of Citanes $t^{\text {tr }}$ but otherwise was quite unpredictable

The results are outlined in Table $\mathbb{I}$ The only popr results ( 2 cases) were obtanned in group $\mathbb{I}$, where 05 per cent Citanest $^{\mathrm{H}}$ was used These were both adult males with infected fingers who complaned of severe pain with surgical stimulation It is interesting to note that they were both analgesic to pin-prick prior to the onset of surgery

TABLE I

\begin{tabular}{|c|c|c|c|c|c|c|c|}
\hline \multirow[b]{2}{*}{ Group } & \multirow{2}{*}{$\begin{array}{l}\text { Strength } \\
\text { of } \\
\text { solution, } \%\end{array}$} & \multirow{2}{*}{$\begin{array}{l}\text { Number } \\
\text { of } \\
\text { patients }\end{array}$} & \multirow[b]{2}{*}{ Age } & \multirow[b]{2}{*}{ Dosage, mg } & \multicolumn{3}{|c|}{ Results } \\
\hline & & & & & Good & Moderate & Poor \\
\hline I & 05 & 20 & $8-40$ & $75-150$ & 15 & 3 & 2 \\
\hline IIIA & 10 & 14 & $6-50$ & $100-400$ & 12 & 2 & 0 \\
\hline IIIB & 10 & 22 & $10-60$ & 200 & 20 & 2 & 0 \\
\hline III & $10 \& 20$ & 2 & $21 \& 37$ & $400 \& 550$ & 2 & 0 & 0 \\
\hline$\pi$ & 20 & 6 & $9-30$ & $300-800$ & 6 & 0 & 0 \\
\hline Total & $05-20$ & 64 & $6-60$ & $75-800$ & $\begin{array}{c}55 \\
(86 \%)\end{array}$ & $\begin{array}{c}7 \\
(11 \%)\end{array}$ & $\begin{array}{c}2 \\
(3 \%)\end{array}$ \\
\hline
\end{tabular}

In group IIA one of the two patients for which the result was moderate was a 13-year-old boy who had recerved only $12 \mathrm{cc}$ of 10 per cent Citanest ${ }^{\mathrm{n}}$ when the injection went interstitial The other patient was a 15-year-old male who gimaced when the incision was made into his infected thumb, but made no further protestation

In group $\mathbb{I I B}$ the two moderate results were again obtaned in young males The first was an 11-year-old boy who had continuous discomfort in a swollen infected thumb following inflation of the tourniquet This discomfort was relieved with surgical incision The second was a 13-year-old male with an infected finger

The two patients in group III each received initially 10 per cent Citanes|r, which was subsequently supplemented with 20 per cent Citanest $^{\mathrm{R}}$ The finst patient, a 21-year-old male, had a traumatic amputation of the distal portion of his thumb Durng cleansing of the wound he complaned of pain and the tourniquet was found to be deflated below the systolic blood pressure A Supplementary dose of $10 \mathrm{cc}$ of 20 per cent Citanest ${ }^{\mathrm{R}}$ was administered following reinflation of the cuff, and surgery was carried out without further discomfort The second patient, a 37-year-old male, had received $25 \mathrm{c} c$ of 10 per cent Citanes $\dagger^{\mathbf{n}}$ However, there was difficulty with the injection, an undetermined amount having gone into the interstitial tissue on two occasions Following this, he had anaesthesia in all areas but the index finger He was then give'n an injection of $15 \mathrm{cc}$ of 20 per cent Citanest ${ }^{\mathrm{R}}$, whereupon complete analgesia was obtained $\mathrm{He}$ had postenor dislocations of his second, third, fourth, and fifth metacarpall-phalangeal joints and a large laceiation across his palm Reduction and suturing were carried out by the surgeon without discomfort to the patient 
Group IV consisted of patients receiving 20 per cent Citanest ${ }^{\mathrm{n}}$ One patient with a mangled hand, who recerved $600 \mathrm{mg}$ of Citanest ${ }^{\mathrm{r}}$, complaned of discomfort in his hand after 1 hour and 21 minutes The cuff had previously been transferred to the anaesthetized area This discomfort was relieved 8 minutes later when the tourniquet was deflated. However, the cuff was remflated after 1 minute because of haemorrhaging and surgery was contmued for another 15 minutes The one panent who recerved $800 \mathrm{mg}$ of Citanest ${ }^{\mathrm{B}}$ complained of dizz1ness and diploplia His symptoms persisted for 30 minutes The blood pressure and pulse remained stable and there was no nystagmus or twitching Approximately two hours later he complained of headache

In addition to the patient mentioned above who received $800 \mathrm{mg}$, there were five patients who received $400 \mathrm{mg}$, and two patients who received $550 \mathrm{mg}$ and $600 \mathrm{mg}$ respectively One 9 -year-old boy seceived $300 \mathrm{mg}$ No complications were noted in any of these patients

Minor complications consisted of (a) complaints of discomfort towards the termination of the injection, variously described as sensations of burning, pins and needles, and fulness, and $(b)$ a local swelling of the tissue, due to leakage at the site of venepuncture

\section{Discussion}

The regional intravenous technique using Citanest $^{\mathrm{r}}$ was an eflective means of producing surgical analgesia in the extremity Citanest $t^{\mathrm{R}}$ appeared to have a low toxicity The only complication in the series occurred in a patient who had received $800 \mathrm{mg}$ of the drug, and who thowed mild neurological symptoms The use of 10 per cent Citanest ${ }^{\mathrm{B}}$ appeared to provide adequate analgesia and a volume of $20 \mathrm{cc}$ seemed to be a sufficient adult dosage While the use of this volume-strength relationship provided a good margin of safety, the volume could be modified for paediatric or geriatric pahents

Occasionally the distribution of analgesia was patchy Since the verns are distended following the imitial injection of the local anaesthetic, a supplemental dose could be given if necessary

The language difficulty may have been partly responsible fol the absence of reported subjective svmptoms

\section{SUMMARY}

The technique of intravenous 1egional anaesthesia was carried out in 64 patients between the ages of 6 and 60 years A new local anaesthetic, $a$-n-propvlamino-2-methylpropionanilide or Citanest ${ }^{\mathrm{R}}$, was used in 05,10 , and 20 per cent strengths, and in a dosage range of $75 \mathrm{mg}$ to $800 \mathrm{mg}$ For this dosage range 86 per cent had good analgesia, 11 per cent moderate, and 3 per cent poor, providing 97 per cent adequate anaesthesia in the senes Poor analgesia occurred in only two cases in which 05 per cent Citanest ${ }^{\mathrm{R}}$ had been used Neurological symptoms appeared in one patient who had received $800 \mathrm{mg}$ of Citanes ${ }^{\mathrm{R}}$ There were no other complications 
RÉSUMÉ

On a prazqué l'anesthésie régıonale intraveuneuse chez 64 malades agés de 6 à 60 ans On a utilisé un nouvel anesthésique local, le a-n-propylamino+2-méthylproprioanilude ou Citanest $t^{\mathbb{R}}$ aux concentrations de 05 pour cent, 1 pour cent, et 2 pour cent et à des doses allant de $75 \mathrm{mg}$ à $800 \mathrm{mg}$ A ces dosages, 86 pour cent ont eu une bonne analgésie, 11 pour cent une analgésite légère et 3 pour cent une analgésie fauble, donc, 97 pour cent ont eu une anesthésie suffisante Les deux seuls cas de faible analgésie avaıent reçu du Citanevt à 05 pour cent On a

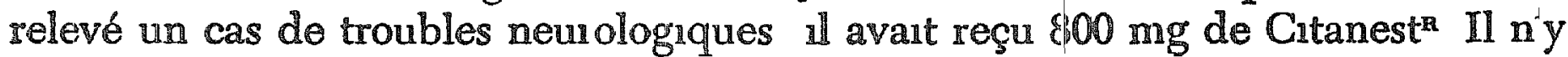
eut pas d'autre complication

The Citanest ${ }^{\mathrm{B}}$ and most of the reference material for the study was kundly donated by Astra, Sweden

\section{REFERENCES}

1 LorGnEN, N \& TEGNER, C Synthesis of Some a-Monalkyliamno-2-methylpropionanilides, a New Local Anaesthetre Acta Chem Scand 14153 (1960)

2 Wieduling, S Studies on a-n-Propylamino-2-methylpropionanlide-A. New Local Anaesthetic Acta Pharmacol 17233 (1960)

3 Astrom, A \& PERsson, N H Some Pharmacological Propertles of a-Methyl-a-propylarninopropionanilide, a New Local Anaesthetic Bnt I Pharmacol 1632 (1961)

4 ERTrSsoN, $\mathbb{E}$ L67-Expenmental Evaluation of a New Local Anaesthetic in Man Actr Anaesth Scand 5191 (1961)

5 von BAfr, V \& ERmsson, E Citanest (L67)-A New Local Anaesthetic. (Eng) SV Lakartadn 592221 (1962)

6 ENGlisson, S, ERIKsson, E, WAELQVist, S, \& ORTHANGren, B Differences in Tolerance to Intravenous Xylocaine and Citanest (L67), a New Local Anaesthetuc A Double Blind Study un Man Proc Ist European Congr Anaerthesiology, Viemna, Sept 3-9, 1982, vol 11, 200-1

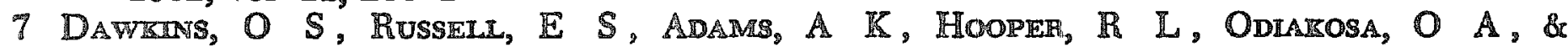
Fleming, S A Intravenous Regional Anaesthesid Canad Anaesth Soc I II 243 (1964) 